\title{
School Backyard Drawings by Kindergarten Students: An Interdisciplinary Experience in the South of Brazil
}

\author{
Ana Gabriela Rocha, Simara Rodrigues Gheno, Jerônimo de Oliveira Loureiro, \\ Rossano André Dal-Farra \\ Lutheran University of Brazil, Canoas City, Brazil \\ Email: anagabrieladasilvarocha@yahoo.com.br, simaragheno@gmail.com, loureirojeronimo@gmail.com, \\ rossanodf@uol.com.br
}

Received 28 August 2015; accepted 20 November 2015; published 23 November 2015

Copyright (C) 2015 by authors and Scientific Research Publishing Inc.

This work is licensed under the Creative Commons Attribution International License (CC BY).

http://creativecommons.org/licenses/by/4.0/

(c) (i) Open Access

\section{Abstract}

The recent urbanization and increasing distance between children and nature have had negative impact both in learning and in the maintenance of healthy life in the natural environment. The development and application of transdisciplinary teaching practices in sciences and visual arts afford to materialize highly relevant strategies in environmental education. Based on these principles, the present study analyzed the possible contributions of transdisciplinary efforts to children's drawings of the environment they live in. Fifteen elementary school children were requested to draw 1) what they remembered of the school backyard; 2) what they remembered of the "nature" in the school backyard; and 3) what they saw during a visit to the backyard. In addition, semi-structured interviews were carried out to collect the children's impressions of their drawings. The results indicate that, in addition to the grass growing in the area, playground features and other toys were consistently represented in drawings, indicating that the backyard is strongly correlated with students' leisure and game activities. When prompted to draw nature elements, trees and some arthropods were drawn, such as insect larvae and bees. For such reasons, it is necessary to improve the students' ties with the natural environment looking for more significant educational practices in relation to the nature in the surroundings where they inhabit.

\section{Keywords}

Environmental Education, Children Education, Children Drawing 


\section{Introduction}

During cognitive development, a child evolves concepts and works up conceptions about the environment it lives in, based mostly on personal experience and the meanings of such understandings. In this sense, the way in which nature is represented by the family, the school, and media productions influences this process, forming the students’ opinions about the natural and man-made environments.

From this perspective, activities covering visual arts and natural sciences afford the elements required to develop new educational practices in children's education.

Considering the scarcity of studies that specifically address the teaching of sciences in elementary education, the main objective of the present study was to identify the conceptions held by students of a community school in south Brazil about the environment they live in, including the school backyard and the public spaces in the city they live in.

\section{Interdisciplinarity, Childhood Education and Environmental Education}

Some characteristics of good practices of environmental education are, among others: 1) participants are actively involved in the education experience; 2) hands-on observation and discovery 3) the educational program is grounded in the particular attributes of a place, "using in situ natural and community systems and themes as the context for learning” (Stern et al., 2014: p. 583).

Based on these premises, educational practices involving art and environmental education are very important. Fazenda (2008) points out that interdisciplinarity means attitude about knowledge involving the culture of the place where teachers are formed.

According to Moraes (1992), it is the exploitation that the child will gradually increase his self-knowledge and, by extension, their knowledge of the world. In this way, through contact with the environment, the child expands his knowledge and builds concepts.

To explore the world around them, children of three and four years of age develop experiments with nature that influence their eyes on the environment, developing their own narratives to represent what they perceive in their world (Wilson, 1996). It is important to remember that encouraging concern for the environment through contact with it, conducting experiments, and discussions of achievements by observation of the environment allow children to develop environmental awareness, becoming critical and attentive to what surrounds them.

The children's drawing contributes to the child being an important aspect to the full development of the individual and this in turn acts as a mediating element of knowledge and self-knowledge. From the drawing, the child organizes information, processes experiences and thought, reveals their learning and can develop a unique style of representation of the world (Goldberg et al., 2005).

According to Antonio and Guimarães (2005), children’s drawings are:

1) More than a simple image to the child, because they materialize the thoughts, recording, on a sheet of paper, elements of their everyday life;

2) A symbolic representation, covering an identity relationship of what it symbolizes, with a web of meanings of their thought both objective and subjective, and is context-dependent.

\section{Methods}

During the year of 2015 six meetings were held with fifteen students from the kindergarten with children aged from four to five who attend a school of Children's Community Education, located in southern Brazil with authorization given by children parents. Students built drawings on different locations, including the backyard, a square and environments such as sea and forest. In the present paper assesses only the information related to the schoolyard. When finalizing the drawings, semi-structured interviews were done with students, seeking to investigate the gaze of students about the environment at the end of each activity performed. Both designs and speeches of the students were categorized from content analysis aiming to understand students perception on the environment depicted in the children drawings to identify the meaning of these drawings for the presence and absence of elements of nature they observed. The results have gone through a screening process from the drawn elements and expressed by children in interviews, presented through descriptive statistics tools (Bauer \& Gaskell, 2008, Cresswell \& Clark, 2011; Cresswell, 2013; Dal-Farra \& Lopes, 2013). 


\section{Results and Discussion}

A diversified set of elements in the drawings were observed, showing that although they were very young, they have an interesting view of where they study. Figure 1 shows the elements perceived in the schoolyard and represented in the drawings made by students when they were in the classroom.

Whereas these were the first drawings made by children without being in the schoolyard, it is clear that there is a strong presence of elements used for the games, especially the playground and toys.

Therefore, based on the children memories, it can be shown that the school environment is for them, predominantly, a place of fun out of the classroom, although they represented, as well as components of the built environment, elements of the natural environment including biotic and abiotic factors. Among the natural aspects were represented grass (66.7\%), the sky (60\%) the sun (46.7\%) and the sand (40\%).

Two students have designed their peers, indicating that the schoolyard plays a role in the interaction between them, as well as the same number of students represented flowers, whose presence in the environment is seasonal. The three animals represented were a bird, a bee, and a rabbit.

The media frequently propagates reports about importance of the preservation of animals under extinction risk. In these texts, we find recidivists references to the mammals. More recently, we observe also an increasing concern with the local species, disseminating the discourse related to necessity of participation in the great global net where we live and, where we cohabit with the different species of animals with several repercussions in school (Dal-Farra, 2004).

Figure 2 refers to the second drawing done in class in the same day but just about nature.

The representations showed grass and sun many times designed by the children although the rainbow appeared
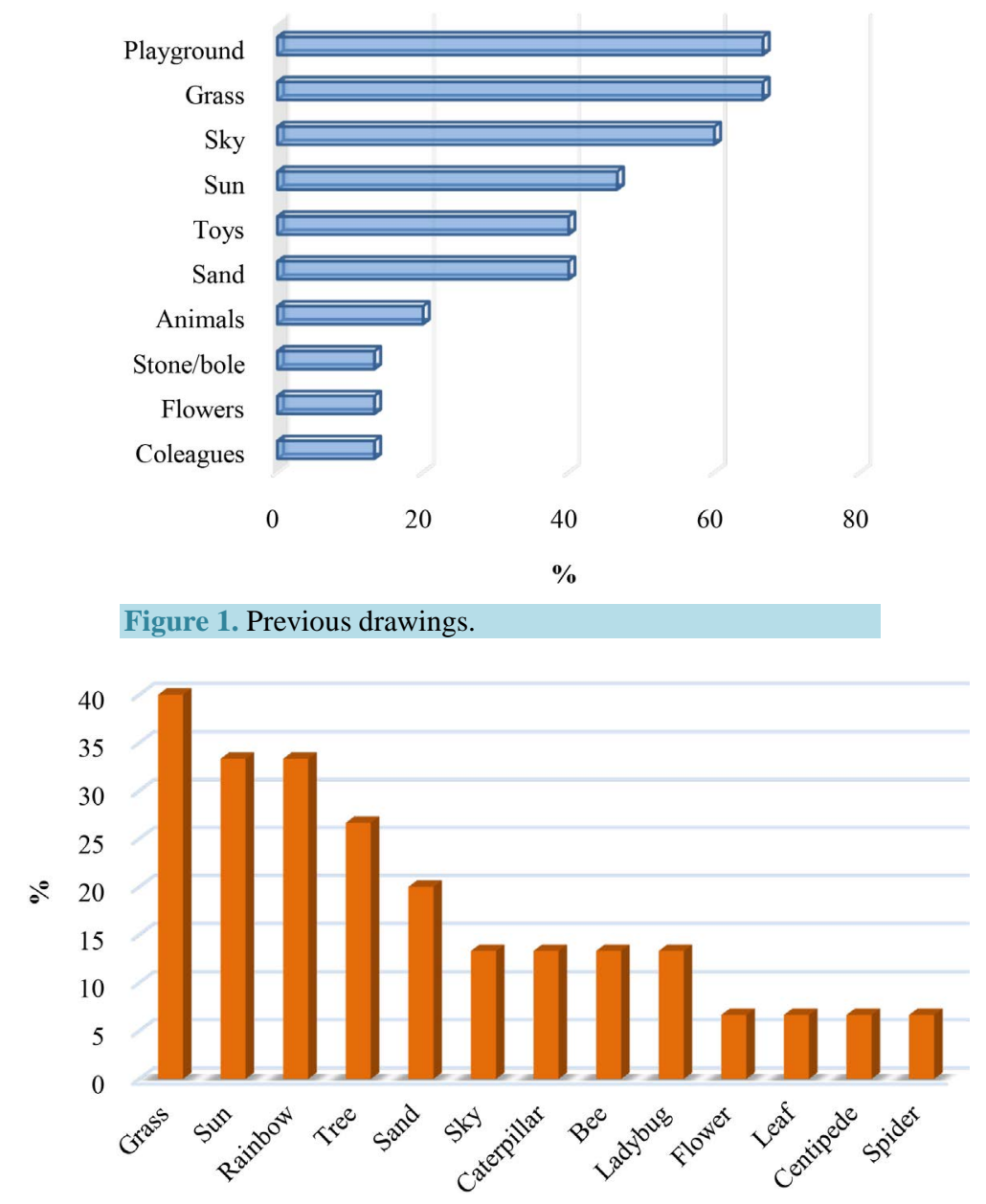

Figure 2. Nature in the backyard according to students. 
in other days not at the specific time when the drawings were made. It can be observed that, in the memory of nature, the students represented the animals, in this case, the arthropods because they frequently are seen on site.

In general, arthropods, like spider, are as undesirables (Davey, 1994), with exceptions including the Ladybug. These animals were mentioned with great emphasis for them in lines, including that the larva, popularly known as "hairy caterpillar", was cited by them for "burn the skin", being, therefore, culturally considered negatively by the students.

It turns out that, when called upon to draw the elements of "nature", $26.7 \%$ of the students remembered the trees, not been previously drawn, just as it is noticed to presence of a high number of arthropods due to the frequency with which occur at school.

According with Wolsey and Lapp (2014) school gardens provide students with opportunities to extend what they learn directly about sustainable food sources and results obtained in this paper supports the same for many subjects related with environmental education.

Figure 3 shows the results obtained with the third drawing, in which children accounted for, after on-site observation, the schoolyard.

There was a considerable difference from the first two drawings for the third represented specially by reducing the number of objects. However, there was a pronounced presence of trees in the drawings because, as observed, the expansion of the children view on natural elements because activities undertaken.

A dialogue with the children was held in respect to what they drew and all the explanations they gave about their drawings were annotated. When asked about how the courtyard of the school and that was therein, they responded as follows:

"It has sand”; "One house and two slides”; "I like to play with sand and swing."

When asked about the nature present in the courtyard they said:

"Nature, is not to kill the animals"; "Nature is green"; "The green bug that blows the caterpillar"; "Nature has to survive, we can't kill the animals"; "Cockroach is also the nature, snake, spider and cricket”; "The tree is quite large and has leaves"; "It weeds in the yard"; "The trees fall, if you cut the tree it falls".

Considering the results, it is very important to increase the access of children to outdoor spaces, because the indispensability of such spaces for early childhood education and for environmental education.

Thinking about interfaces between conservation and education, according with Miller (2005):

Biodiversity loss is a matter of great concern among conservation scientists, but the wherewithal to reverse this trend is generally lacking. One reason is that nearly half of the world's people live in urban areas and are increasingly disconnected from nature. If there is to be broad-based public support for biodiversity conservation, the places where people live and work should be designed so as to provide opportunities for meaningful interactions with the natural world (Miller, 2005).

According with Uno (2009) about botany literacy and education, there are some principles. Here we state two of them:

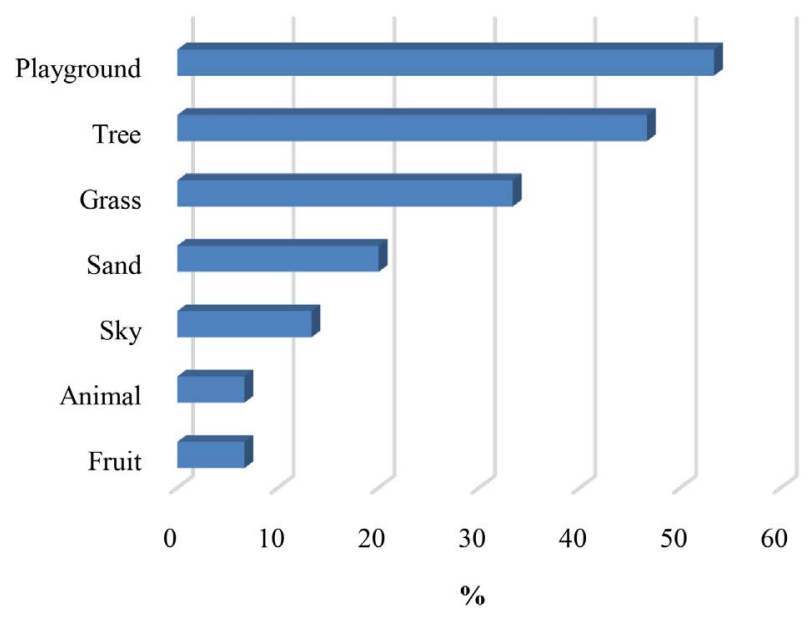

Figure 3. Drawings made after see the backyard. 
- Learners' motivation to learn and sense of self affect what is learned, how much is learned, and how much effort will be put into the learning process

- Learning is enhanced through socially supported interactions.

Based on these premises, we need to develop strategies to teach environmental education to children and School backyard is quite suitable for this.

\section{Conclusions}

It may be noted that the look of children on the school is geared primarily to leisure space provided for therein site and the toys, although they also have been represented natural elements such as the sky, the sun and grass. The animals appeared represented, particularly arthropods observed in the schoolyard. However, this needs to be better worked with children, as it was observed at the time they were asked to design elements of nature, as in the later design the observation of the schoolyard when, after urged to better understand the nature, the students inserted the trees in the drawings.

For such reasons, the realization of interdisciplinary activities that provide interaction between the arts and natural sciences provides a closer look at nature, and can contribute to the conservation and preservation of natural spaces. Thus, integrating students with the environment, providing moments in environments where the child can interact and reflect on them, the child begins to develop its position in comparison to what surrounds him; it is dialogue on the environment and understanding on how it works and what moves habits and behaviors.

\section{Acknowledgements}

Coordenação de Aperfeiçoamento de Pessoal de Nível Superior (CAPES) for Scholarships.

\section{References}

Antonio, D. G., \& Guimarães, S. T. L. (2005). Representações do meio ambiente através do desenho infantil: Refletindo sobre os procedimentos interpretativos. Educação Ambiental em Ação, IV, 14. http://www.revistaea.org/artigo.php?idartigo=343

Bauer, M., \& Gaskell, G. (Eds.) (2008). Qualitative Researching Whit Text, Image, and Sound. London: Sage.

Cresswell, J. D. (2013). Research Design: Qualitative, Quantitative, and Mixed Methods Approaches (4th ed.). Los Angeles, CA: SAGE.

Cresswell, J. D., \& Clark, V. L. P. (2011). Designing and Conducting Mixed Methods Research (2nd ed.). Los Angeles, CA: SAGE.

Dal-Farra, R. A. (2004). Educação e representações: Configurações em rede na mídia e no ambiente. Pró-posições, 15, 165-172.

Dal-Farra, R. A., \& Lopes, P. T. C. (2013). Métodos mistos de pesquisa em educação: Pressupostos teóricos. Nuances: Estudos sobre Educação, 24, 67-80. http://dx.doi.org/10.14572/nuances.v24i3.2698

Davey, G. C. L. (1994). The "Disgusting” Spider: The Role of Disease and Illness in the Perpetuation of Fear OF Spiders. Societyand Animals, 2, 17-25. http://dx.doi.org/10.1163/156853094x00045

Fazenda, I. (2008). O que é interdisciplinaridade? São Paulo: Cortez.

Goldberg, L. G., Yunes, M. A. M., \& Freitas, J. V. (2005). O desenho infantil na ótica da ecologia do desenvolvimento humano. Psicologia em Estudo, 10, 97-106. http://dx.doi.org/10.1590/s1413-73722005000100012

Miller, J. R. (2005). Biodiversity Conservation and the Extinction of Experience. TRENDS in Ecologyand Evolution, 20, 430-434. http://dx.doi.org/10.1016/j.tree.2005.05.013

Moraes, R. (1992). Ciências para séries iniciais e alfabetização. Porto Alegre, Sagra: DC Luzzatto.

Stern, M. J., Powell, R. B., \& Hill, D. (2014). Environmental Education Program Evaluation in the New Millennium: What Do We Measure and What Have We Learned? Environmental Education Research, 20, 581-611. http://dx.doi.org/10.1080/13504622.2013.838749

Uno, G. E. (2009). Botanical Literacy: What and How Should Students Learn about Plants? American Journal of Botany, 96, 1753-1759. http://dx.doi.org/10.3732/ajb.0900025

Wilson, R. A. (1996). The Earth: A Vale of Soul Making. Early Childhood Education Journal, 23, 169-171. http://dx.doi.org/10.1007/BF02364754

Wolsey, D. T., \& Lapp, D. (2014). School Gardens: Situating Students within a Global Context. Journal of Education, 194, 56. 